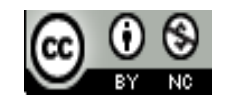

Journal of Education, Teaching, and Learning is licensed under A Creative Commons Attribution-Non Commercial 4.0 International License.

\title{
MANAgEMENT OF Filial SCHOOL DEVELOPMENT (Case Study on Management Standards on Singkawang 11 State JUNIOR HIGH SCHOOL)
}

\author{
Yusak Ujang ${ }^{1)}$, M.Syukri ${ }^{2)}$, Sukmawati ${ }^{3)}$ \\ 1), 2),3) Universitas Tanjungpura, Pontianak, Indonesia \\ E-mail: yusacujang@rocketmail.com
}

\begin{abstract}
The filial school is one of the model of school development where learners study and learn various skills as the basic capital to continue to higher education level. The responsibility of the school's management is fully filial by the parent school in accordance with the quality standards of education services. This research aims to reveal the management of philial school development on the standard of management at Singkawang 11 State Junior High School (SMP Negeri 11 Singkawang ) with the focus of: 1) development planning of filial school in management standard, 2) organizing the development of filial school in management standard, 3) implementation of filial school development on management standard, 4) supervision of filial school development on management standards, 5) constraints faced in the development of filial schools on management standards, and 6) efforts undertaken in the development of filial schools on management standards. The research method used descriptive research with qualitative approach. Data collected by in-depth interviews, participant observation, documentation and analyzed by data reduction, data presentation, conclusion or verification. Testing of data reliability is done by extending the observation period, and triangulation and member checking. The results of the study conclude: 1) Filial School Development Planning in Management Standards, has been done by Singkawang 11 State Junior High School by making the vision and mission is implied that support the implementation of philial school development and has been socialized and arranged based on consultation with certain teachers by considering the needs of the school as a basis making, 2) organizing the development of filial schools on the standard of management, that the head of Singkawang 11 State Junior High School has arranged the organizational structure in connection with the division of main tasks and functions of the teacher and socialized. 3) Implementing the development of filial schools on the standard of management that Singkawang 11 State Junior High School refers to document I which includes all aspects of school management including philial schools covering curriculum aspects, student aspects, educator aspect and educational staff, aspects of facilities and infrastructure, finance and financing, school culture and school areas, school committees and partnerships, and school management information systems, 4) supervision of filial school development on process standards, that Singkawang 11 State Junior High School has conducted School Self Evaluation (EDS) conducted annually as a basis for preparation of the Plan School Work (RKS) and principals have conducted classroom supervision activities on teachers. For managerial supervision of the eight national standards of education by school supervisors has been undertaken but not scheduled, 5) The barriers faced in the development of filial schools in management standards consist of internal (internal) and external (external) barriers. obstacles from within include the limitations of learning facilities and infrastructure of students in the form of limited learning buildings, laboratories, libraries, canteen, prayer room, learning books and desks and student learning seats. External obstacles in the form of poor, perforated, and muddy access roads make it difficult for teachers to carry out teaching duties at the filial schools. 6) The efforts made in the development of filial schools in the management standards include the proposal for the rehabilitation of the 2017 study by the principal to the education and cultural offices of Singkawang city, the cooperation of the principal of Singkawang 11 State Junior High School with Singkawang 3 State Junior High School in a grant program of learning facilities in the form of help desk and desk study as well as reference books for studying students in filial schools.
\end{abstract}

Keywords: Development Management; Filial Schools; Management Standards 


\section{INTRODUCTION}

The development of formal schools can be done in various ways or models. One of them is the development of filial schools. Filial according to Big Indonesian Dictionary (1995: 191) is "branch (company, school and so forth ...)". Meanwhile, according to Rusdy Nurdiansyah in Wikipedia (https://en.wikipedia.org/wiki/Filial: August 5, 2015): "filial is another word of a remote class, the class that opened outside the main school is intended for students who are not accommodated in the school either due to limited seats (classroom) or distance to distant students living with studying age of seven to eighteen or nineteen (https://id.wikipedia.org/wiki/Filial) ".

The development of a filial school is explicitly set out in Government Regulation No. 17 of 2010 on Management and Implementation of Education in Chapter VII: Special Education and Special Service Education. Article 140 states "(1) Special service education may be conducted on formal, nonformal, and informal education channels. (2) Special education services on formal education channels are organized by adjusting the time, place, facilities and infrastructure of learning, educators, education personnel, and/or other learning resources with the conditions of student difficulties. Article 141 states that "Government and/or local government in accordance with their respective authorities provide special service education." Filial School is a formal school of special service category that is held due to limited capacity and distance for students to school parent (https: // id. Wikipedia .org / wiki / Filial). Another factor required the development of a filial school is as an effort to advance the educational organization. Educational institutions will not advance without the help of a helpful organization. As Rusdiana (2016: 292) puts it, "Educational institutions will not advance without the help of a helpful organization. Similarly, new organizations can change institutional steps. This is because the organization is where people who have a goal".

The management of the filial schools is entirely to the parent school in collaboration with the provincial and district/municipality education and cultural offices by implementing school-based management that is demonstrated by independence, partnership, participation, openness, and accountability. This is in accordance with the Government Regulation of the Republic of Indonesia Number 19 Year 2005 on National Education Standards article 49 paragraph (1) states: "Management of educational units at primary and secondary education level implements school-based management as indicated by independence, participation, openness, and accountability". Furthermore, in Article 50 paragraph (1) states that
"Each educational unit is headed by the principal as responsible for the management of education". Thus, the principal has full authority in managing all school activities including the management of the filial school by involving all relevant elements in it which include the school community and the education council especially in decision making (Article 51 paragraph 1 of the Government Regulation of the Republic of Indonesia No. 19 of 2005). The filial parent school is the management center of the filial school so that curriculum and policy management related to the learning process follows the standard of parent-school management. The standard of management as set forth in article 52 of Government Regulation Number 19 Year 2005 reads "Every educational unit should have guidance which regulates: a) the curriculum of education and syllabus units, b) educational/academic calendar, showing all categories of educational unit activities for a year and monthly, monthly and weekly detailed, c) educational unit organizational structure, d) distribution of tasks among educators, e) assignment of tasks among education personnel, f) academic regulations, g) discipline of educators, education personnel and learners, and the use and maintenance of facilities and infrastructure, h) code of ethics of relations between fellow citizens within the educational unit and the relationship between citizens of education units with the community ". Development and management of filial schools can be done at all levels of formal education both primary and secondary education level. The filial school is part of the management of the development of educational organizations which can be interpreted as an effort to manage the consequences caused by changes in educational organizations both from within and from outside (Rusdiana, 2016: 295). In an effort to realize and improve the quality of filial school required a good management and directed. The output quality (output) of the filial school is at least the same as that of the parent school. Such good and targeted management includes school program planning, organizing, program implementation, supervisory / evaluation and school information systems (Muhammad Farid \& Daryanto, 2013: 1)

State Junior High School 11 Kota Singkawang is one of Junior High School in Singkawang City that organizes a filial school. This is in accordance with the Letter of Duty issued by the Head of Education Department of Singkawang City No. 094/230 / Diknas.A. This school is located in the Eastern part of Singkawang City precisely on Jalan Sebakuan, Mayasopa urban village. Established in 2006 and inaugurated by the mayor of Singkawang. This school is directly adjacent to Bengkayang Regency and Sambas Regency. The desire of the community to get education makes this school pretty much get students every year. Some of them are students from 
Bengkayang and Sambas districts. The filial school at 11 State Junior High School is held in 2015 and is located in Seluang Kelurahan Mayasopa. The policy of Singkawang City Government to hold a filial school at 11 State Junior High School is based on low Gross Participation Rate (APK) in education level, especially Junior High School in Singkawang City. As an effort to improve the APK in junior high school level, a filial school was held at several Junior High Schools in Singkawang City, one of them is Singkawang 11 State Junior High School. Distance filial school with 11 State Junior High School is 10 kilometers. Damaged road conditions and the absence of public transportation paths cause filial schools to be one of the best alternatives in reducing dropout rates among students who have problems in following the learning activities at Singkawang 11 State Junior High School. In addition, with the presence of filial schools expected gross enrollment rate (APK) every year can increase significantly in the city of Singkawang and in East Singkawang district in particular.

Implementation of filial schools at 11 State Junior High School gets full support from Singkawang City Government. Development management starting from planning, organizing, implementing and monitoring is done jointly between Education and Culture office of City of Singkawang with 11 State Junior High School as executor with reference to one of national standard of education that is management standard. The quality of good management, integrated, partnership, participation, self-reliance, transparency, and accountability at 11 State Junior High School in managing the filial school get positive response and support from society. This can be seen from the increasing number of students who enroll in the filial school. From 2015 to 2017 , the number of students in Singkawang 11 State Junior High School, filial schools from grades 7,8 and 9 is 99 students (8355 Singkawang 11 State Junior High School lesson year 2017/2018). Communities (learners) who feel greatly helped by the access to education through filial schools. For parents, their children do not have to go far to school and the same quality of education as other schools.

From the background and some of the reasons that the researcher described above, this research focuses on the in-depth study of filial school development management that focuses on the standard of management at Singkawang 11 State Junior High School.

\section{Methodology}

The research method used descriptive research with qualitative approach. the location of the research was conducted at the filial school at Singkawang 11 State Junior High School especially in the management standard. Data collected by in-depth interviews, participant observation, documentation and analyzed by data reduction, data presentation, conclusion or verification. Testing of data reliability is done by extending the observation period, and triangulation and member checking. The procedure in this study consists of 3 stages, namely:

\section{A. Pre-Research Phase}

Some activities are done before the researchers enter the field. Individuals are (1) preparation of the initial design of the research, (2) management of research permits, (3) field assessment and completion of research design, (4) selection and interaction with subjects and informants; and (5) field. It should be noted, researchers are interested in the facts or symptoms of the development of filial school management and social consequences. Fifth observations have been made long before the research designs were prepared and put forward as research topics. Armed with preliminary observation and literature review, the researcher proposed a research about the management of filial school development at Singkawang 11 State Junior High School. The proposed proposal should be consulted with the supervisor and will be invited by inviting colleagues and experts. Because using a qualitative approach, this research proposal is considered tentative. Therefore seminar opportunities are used to capture criticism and suggestions, both on topics and research methods. Based on these critiques and inputs, the researcher adjusted the research design and conducted the field assessment.

Field assessment is done with three techniques simultaneously and flexure that is (1) observation; researchers observed directly about the planning management conducted by the Principal and other elements in Singkawang 11 State Junior High School, (2)interview; in-depth researchers interviewed several informants, (3) document review; researchers select and record the relevant document data Problem formulation and selection of methods of research is more precisely done again based on the assessment of the field (grand tour observation). Throughout the field activities, of course, the center of attention and techniques continue to experience sharpening and adjustment.

\section{B. Field Activity Stage}

In the implementation of this research, there are changes and improvements. Not only concerns the focus of research, but also on research methods. The sample concept in this study is related to selecting informants or social situations that can provide information steady, true and reliable about the elements of research center of attention. The selection of informants followed the snowball pattern (snowball sampling). If the introduction and social interaction with the informant are questioned then it is asked to that person who else is known or called indirectly by him. In determining the amount and 
time to interact with the data source, the researcher uses the sampling concept suggested by Lincoln and Guba in Sugiyono (2009: 54) that is maximum variation sampling to document unique variations. The researcher will stop the data collection if from the source data is no longer found new body. With this concept, the number of data sources is not the main concern, but rather the complete acquisition of information with the diversity that exists. Not sure all the informants of the leadership elements provide the necessary data. Because of the informant as a source of data interviewed in depth. Each of them is 4 members of leadership, 3 educators, and 1 administrative staff. Because the main data of this study were obtained based on the interaction with the informants in the natural setting, some equipment was prepared only for convenience, such as: (1) stationery, (2) interview guides and Samsung type A5 recorder and photos using Samsung Galaxy Tab Android S, including field note sheets. This equipment is used when not interfere with the fairness of social interaction.

With interview researchers trying to get information with face to face physically and to ask questions with informants. With this technique, researchers play a role as data collection tool. During the interview, researchers will also look at the behavior of informants in answering questions. With researchers always trying to take advantage of opportunities and places-the most appropriate place to conduct interview.

\section{Post-Field Stage}

After each field research activity is done, then all findings or data obtained by Triangulation, namely testing the credibility as checking data from various sources, ways and time, including: data processing, data reduction, data selection, grouping and presentation of data into patterns and consultations, defining themes, theme analysis and completeness of data and consultations, testing the validity of data based on data groups and consultations, drafting/drafting reports and consulting, preparing research and consultation reports, test results (thesis examinations), improvement of thesis and consultation, submission of reports.

\section{RESULTS AND DISCUSSION}

A. Research Results

1. School Filial Development Planning

Based on the results of analysis of research data about filial school development planning on the standard of management at Singkawang 11 State Junior High School hence some findings in this research that is school has vision and mission which compiled and disseminated with school citizen. The filial school development program is already written in the school mission. Vision and mission are based on the school's need for quality improvement. There is an annual school work plan (RKS) prepared together with the teacher team and school committee. RKS is made for one academic year and based on the needs of eight national education standards (SNP). The development of a filial school is already included in the RKS made by the parent school. The component of school development is based on assignment letter number 090/230 / Diknas.A, issued by the head of Department of Education and Culture of Singkawang city which is focused on the learning process by maximizing the role of educators in Singkawang 11 State Junior High School and honorary staff recruitment Dinas Pendidikan and Culture of Singkawang city. Besides, there is addition of school facilities and infrastructure by increasing partnership with outsiders in the form of cooperation with PT. Darmex Agro and PT. Tanjung RHU in the ground leveling and school field as well as submission of aid proposal to the Education and Culture Office for the addition of study room in the form of rehabilitation School building in 2017.

2. Organizing School Filial Development

Based on the results of data analysis of the research on organizing the development of filial schools on the standard of management at Singkawang 11 State Junior High School the positive trend that became the finding that there is already an organizational structure created by the principal together with the teacher team. The organizational structure is made with attention to the competence of each teacher. The principal holds command and coordination functions within the organizational structure. The organizing of the main tasks and functions of school principals and teachers has been implemented with reference to the task-sharing document in the form of a decree on the appointment of the principal by the mayor of Singkawang (for the principal), and a decree on the distribution of teaching tasks by the principal (for teachers). Organizing is followed up with a schedule of implementation of learning/teaching process.

3. Implementation of Filial School Development

From the analysis of research data about the implementation of filial school development on the standard of management at Singkawang 11 State Junior High School found a positive trend that is there is a document supporting the development activities of filial schools called the document I school compiled by the curriculum development team (TPK) formed by the principal and disseminated at the board meeting of teachers. The development of curriculum field and the field of filial school student affair refers entirely to the master school of Singkawang 11 State Junior High School . For the development of the field of educators and educational personnel fully use the educators from Singkawang 11 State Junior High School and coupled with 
honorarium GTT recruited by the education and cultural office of Singkawang city in 2015. Development of facilities and infrastructure has been implemented in the form of rehabilitation of classrooms from the education office and Singkawang city culture in 2017 . The development of filial school financing is fully managed by Singkawang 11 State Junior High School as a holding school through School Operational Assistance (BOS) fund. The development of culture and work environment follow the master school of Singkawang 11 State Junior High School. For the development of community participation and partnerships have been implemented by establishing a committee of filial schools and establish cooperation with oil palm plantation companies as a form of school partnerships. The information system and management of filial schools are still manual. All information about filial schools is delivered through meetings by inviting parents or community and managed by Singkawang 11 State Junior High School. The parties involved in the development of filial schools are the education and cultural offices of Singkawang city, the headmaster and the board of teachers of Singkawang 11 State Junior High School and the school committee as part of the community

4. Supervision of Filial School Development

Based on the results of data analysis of research on supervision of filial school development on the standard of management, the positive trend that became the findings in this research is the school self-evaluation activities have been implemented by the school involving the curriculum development team (TPK). EDS is implemented as a foundation for policymakers and the preparation of school work plans (RKS). Academic supervision program has been implemented by the principal by involving the teacher team orally. Schedule and execution of supervision has been made and implemented. There is an instrument of supervision with aspects of the assessment of learning tools and processes. Followup supervise has been implemented but not maximal ie there is no report of supervision result in document form. Teacher understanding about supervise is good enough but there are still some teachers who think supervise is only limited to the formalities have not lead to efforts to improve the quality of teaching. For supervisory supervision by the school supervisor has been implemented but only done in the parent school and not yet thoroughly to the filial school. The supervised aspect includes eight national education standards. School filial rarely visited and monitored by the supervisors and education and cultural offices of Singkawang city directly. The supervisory mechanism is only done by listening to information obtained from teachers teaching in a filial school or principal from filial school.

5. Barriers In Filial School Development
Based on the results of analysis of research data about the obstacles faced in the development of filial schools in the management standard, the findings are found that there are barriers from within and from outside. Barriers from within are limited educators on certain subjects such as physical education, health and sports subjects, and art teachers. While external obstacles are in the form of access roads to damaged filial schools, especially during the rainy season, causing teachers from primary schools to have difficulty in carrying out teaching tasks and sometimes have to ridicule the costs incurred by the teachers themselves.

6. Efforts made in Overcoming Barriers in Filial School Development

Based on the results of data analysis of research on efforts made to overcome barriers in the development of filial schools, it was found that has made efforts to submit proposals to the addition of new classrooms at the school filial. In addition, the procurement of partnership activities with plantation companies is not far from the school location to help flatten the uneven schoolyard and hoarding the road to the filial school.

\section{CONCLUSION AND SUGGESTION}

\section{A. Conclusion}

Based on the research findings and discussion of the results in the previous section, the management of the development of filial schools at Singkawang 11 State Junior High School on management standards can be summarized as follows:

1. Development planning of filial school in management standard has been done by arranging vision and mission that support Singkawang 11 State Junior High School as main school in developing filial school. Vision and mission have been socialized and organized based on consultation with the team of teachers by taking into account the needs of schools and communities. This means that the formulation of school vision and mission is appropriate and refers to program planning in management standards. School Work Plan (RKS) prepared and made by the principal every year together with the teacher team and has included the development of a filial School with a development component on process standards, educator and educational standards and infrastructure standards.

2. Organizing the development of Filial School In the standard of management, that the head of Singkawang 11 State Junior High School has compiled the organizational structure in relation to the division of main tasks and functions of teachers and socialized in the environment of 
Singkawang 11 State Junior High School and School filial. The basis of the organizational structure and the division of the main tasks and functions of the teacher is the Principal Decree (SK) on the distribution of teacher duties and is based on teacher competence. Principal in performing its duties based on decree (SK) appointment of principal issued by the mayor of Singkawang. This means that the organization of filial school development is in line with the standard of management.

3. Implementing the development of the Filial School on the Management Standard that State Junior High School 11 Singkawang refers to document I covering all aspects of school management including filial School covering curriculum aspect, student aspect, educator aspect and educational staff, facilities and infrastructure aspects, finance and financing, school culture and environment, school committee and partnership, and school management information systems. This means that the implementation aspect of filial school development is in accordance with the Management Standard.

4. Supervision of filial school development on the standard of management, that Singkawang 11 State Junior High School has conducted School Self Evaluation (EDS) conducted annually as the basis for the preparation of School Work Plan (RKS). EDS activities involve specific teachers according to the capacity of each teacher within the school's organizational structure. Besides, the principal has conducted a class supervision of teachers at Singkawang 11 State Junior High School who is also a teacher at the school filial. supervision activities carried out by teacher team involvement mechanisms, For supervision of managerial eight national standards of education by school, supervisors have been implemented but not scheduled. This means that the supervisory aspect has been implemented with reference to the management standard.

5. Obstacles faced in developing a filial school The management standard consists of internal (internal) and external (external) barriers. Internal obstacles include the limited facilities and learning infrastructure of students in the form of limited learning buildings, laboratories, libraries, canteen, prayer room, learning books and desks and student learning seats. While external obstacles in the form of access roads damaged, perforated and muddy which makes it difficult for teachers to carry out teaching obligations in filial School.

6. The efforts undertaken in the development of the Filial School of Management Standards include establishing partnerships with private parties namely PT. Darmex Agro palm oil and PT. Tanjung RHU is in the form of ground leveling around the school and hoarding of perforated roads leading to filial schools. Besides that, there are proposals for the rehabilitation of learning room in 2017 by the headmaster to the education and cultural office of Singkawang city, the cooperation of the head of Singkawang 11 State Junior High School with Singkawang 3 State Junior High School in the learning support grant program in the form of the support of chairs and desks and reference books for studying students at the filial School.

B. Suggestion

In accordance with the research findings, the results and conclusions presented above, it is advisable to other researchers to be able to conduct further research related to the development of filial School, not only on management standards but on other national education standards so that the existence of filial school and its development is expected to be true. can really provide a positive impact on the community, especially those who have problems in education.

\section{REFERENCES}

Badan Pusat Statistik Kota Singkawang. 2016. https://singkawangkota. bps. go.id.

Daryanto dan Mohamad Farid. 2013. Manajemen Pendidikan di Sekolah. Yogyakarta,Penerbit Gava Media

Peraturan Pemerintah Republik Indonesia nomor 17 tahun 2010 tentang Pengelolaan dan Penyelenggaraan Pendidikan Pada Bab VII: Penyelenggaraan Pendidikan Khusus dan Pendidikan Layanan Khusus.

Peraturan Menteri Pendidikan Nasional Nomor 19 Tahun 2007 tentang Standar Pengelolaan.

Peraturan Pemerintah Nomor 19 tahun 2005 tentang standar nasional pendidikan

Rusdiana. 2016. Pengembangan Organisasi Lembaga Pendidikan. Bandung. Pustaka Setia

Rusdy Nurdiansyah. 2015. https://id.wikipedia.org/wiki/Filial.

Sugiyono. 2014. Memahami Penelitian Kualitatif. Bandung. Alfabeta.

Tim Pustaka Phoenix. 2009. Kamus Besar Bahasa Indonesia. Medan. Pustaka Phoenix. 